\title{
Potential of Entomopathogenic Nematodes as Bio-Control Agents of Sweet Potato Weevil, Cylas formicarius (FABRICIUS) (Coleoptera : Brenthidae)
}

\author{
H. M. R. K. EkANAYAKE ${ }^{1}$, A. M. C. P. Abeysinghe \\ and Yukio TOIDA ${ }^{2}$
}

\begin{abstract}
In this study, the efficacy of two entomopathogenic nematodes species against the potato weevil, Cylas formicarius, a serious pest of sweet potato in Sri Lanka was evaluated. In the laboratory, Heterorhabditis megidis produced $80-90 \%$ mortality of larvae, pupae and adults while Steinernema feltiae produced $70-80 \%$ mortality. In a small plot experiment under field conditions also showed significant insecticidal efficacy on the weevil thereby reducing damage to local sweet potato varieties, CARI-426, CARI-426-13. Although carbofuran gave a considable reduction in damage by the weevil, the degree of control was significantly less than those of two nematode species. A field experiment conducted in large pots with the variety, Wariyapola Red, showed low levels of weevil control due to $S$. feltiae or carbofuran. However, $H$. megidis produced significantly higher levels of weevil control than S. feltiae or the chemical. Results of the experiments on potential of two entomopathogenic nematode species showed a possibility of biological control measure against sweet potato weevil in Sri Lanka. Jpn. J. Nematol. 31 (1/2) : 19-25 (2001)

Keywords: biological control, entomopathogenic nematode, Heterorhabditis megidis, Sri Lanka, Steinernema feltiae, sweet potato weevil
\end{abstract}

Sweet potato, Ipomoea batatas, is an important food crop in Sri Lanka. Total cultivation of sweet potato is around 9,000 ha $(5)$. Sweet potato is attacked by several pests, the most destructive pest of which is the weevil, Cylas formicarius. About 60 to $90 \%$ yield loss by the weevil in all sweet potato growing area has been observed in the country. Continuous cropping of sweet potato throughout the year results in multiplication of the weevil population to damaging levels within a short period of time. Cultural, physical and chemical control can be used to effectively manage the weevil population in the field (9). Farmers have practiced such cultural control of the weevil damage as crop rotation, removal of crop debris, early harvesting, mounding of soil around plants or proper irrigation. Use of Alocasia and Glyricidia leaf mulches effectively prevents weevil attack compared to treatment (3). Frequent use of insecticides, mostly carbofuran, to manage weevil population is also common among farmers. However, the cryptic nature of the insect, which develops within vines and root of sweet potato plants, reduces the effectiveness of insecticides. Bio-control of agricultural pests has been received as a prominent strategy to prevent environmental hazards during the recent past. Reported information on the use of bio-control agents in controlling the sweet potato weevil in Sri Lanka is very meager.

${ }^{1}$ Horticultural Crop Research \& Development Institute, Peradeniya, Sri Lanka.

${ }^{2}$ Former Japan International Research Center for Agricultural Sciences, 1-1, Ohwashi, Tsukuba, Ibaraki 305-8686, Japan. 
Entomopathogenic nematodes of the genera Steinernema and Heterorhabditis which evolved from bacterial feeding microbotropic rhabditoides, have shown a great potential as bio-control agents of Cylas spp. $(1,8)$. These studies have repeatedly shown that both Steinernematid and Heterorhabditid nematodes have suppressed the weevil populations by $68 \%$ and $83 \%$, respectively (6). However, in Sri Lanka, no attempt has been made to control sweet potato weevil using bio-control agents. Hence, laboratory and field investigations were carried out to evaluate the efficacy of two entomopathogenic nematodes, Steinernema feltiae and Heterorhabditis megidis as bio-control agents of sweet potato weevil, Cylas formicarius using three local varieties of sweet potato, CARI-426, CARI-426-13 and Wariyapola Red.

\section{MATERIALS AND METHODS}

Three experiments were conducted at Horticultural Crop Research and Development Institute in Peradeniya. Adult insects were reared on sweet potato tubers in culture cages in the laboratory. Commercial products of entomophathogenic nematodes were obtained from Koppert International. Trade names of these nematode culture are LARVANEM (H. megidis) and ENTONEM ( . feltiae). Each 250g packet of these products should contain 50 million third stage juvenile of these nematodes. As some nematode juveniles were found dead in these products, the number of live nematode juveniles of each product was estimated and $1 \mathrm{~g}$ of each ENTONEM and LARVANEM contained $17 \times 10^{3}$ and $950 \times 10^{3} \mathrm{ju}-$ veniles, respectively. Hence, the weight of the product needed to give required polulation density for different treatments for each experiment was calculated.

Experiment 1. Laboratory bioassay (Impregnated filter paper method)

Three treatments (control-T1, H. megidis $\left(475 \times 10^{3}\right.$ juveniles $/ 100 \mathrm{ml}$ of water) $-\mathrm{T} 2$ and S. felatiae $\left(4.25 \times 10^{3}\right.$ juveniles $/ 100 \mathrm{ml}$ of water) $\left.-\mathrm{T} 3\right)$ were evaluated separately against adult, larval and pupal stages of the weevil. These dosage were indicated in the level of product as recommended dose for weevil. The nine treatments were arranged in a two-factor factorial design with three replicates. Two $\mathrm{ml}$ of each nematode suspension was introduced into plastic petri dishes in which $(8.7 \mathrm{~cm}$ in inner diameter and $1.5 \mathrm{~cm}$ in height) the bottom was covered with a sheet of filter paper and moistened with one $\mathrm{ml}$ of deionized water. Twenty minutes after the nematode suspension was transferred to the petri dish, 20 adults (10 males and 10 females), fourth instar larvae or pupae of the control treatment in each case. Petri dishes were covered with black polyethylene sheet and kept at $25.5 \pm 2{ }^{\circ} \mathrm{C}$. The mortality of larvae, pupae and adults was recorded at 24,48 and $72 \mathrm{hr}$ after exposure. The results were subjected to analysis of variance and the treatment means were compared with least significant difference (LSD) test at $\alpha \leqq$ 0.05 .

\section{Experiment 2. Mini plots}

Four treatments (infested only (control) ) $-\mathrm{T} 1$, Infested $+H$. megidis $-\mathrm{T} 2$, Infested + S. feltiae $-\mathrm{T} 3$ and Infested + carbofuran-T4) were used for both varieties of sweet potato CARI-426-13 and CARI 426. Factorial conbinations of the two varieties with weevil control treatments were arranged in a randomized complete block with 4 replicates. Raised beds of $0.5 \times 2 \mathrm{~m}^{2}$ filled with a compost mixture were prepared in the field and 10 stem cuttings of each sweet potato variety were planted in each bed at $20 \mathrm{~cm}$ apart. Fifteen days after planting, five pairs of weevil are released at the base of each vine to ensure a uniform infestation of the pest. The suspension of $255 \times 10^{3}$ juveniles of $S$. feltiae and $1,235 \times 10^{3}$ juveniles of $H$. migidis $/ 1,000 \mathrm{ml}$ were prepared and 20 days after planting, $100 \mathrm{ml}$ of each nematode suspension was introduced into three holes $(1.5 \mathrm{~cm}$ diameter and $8 \mathrm{~cm}$ depth $)$ made around each vine. Carbofuran was applied to the soil at the time of planting at $2 \mathrm{~kg}$ a.i./ha. The crop was harvested at three and a half month 
after planting and percentage weevil damage was recorded in weight basis i.e. weight of weevil damaged tubers vs. total tuber yield. Results were subjected to analysis of variance and the treatment means were compared using DUNCAN's multiple range test.

Experiment 3. Field efficacy test

Dosage of $H$. megidis, $S$. feltiae and carbofuran used in mini plot study were further evaluated under field conditions for their efficacy in controlling the weevil. An untreated control was also included into treatments where neither chemical insecticide nor bio-control agent was used. All treatments were applied on to plots of $4 \times 0.5 \mathrm{~m}^{2}$, in which 20 stem cuttings of sweet potato variety Wariyapola Red were planted at $20 \mathrm{~cm}$ apart. The treatment were arranged in a randomized complete block with four replicates. The crop was harvested at three and a half months after planting and pertcentage weevil damage was recorded in weight basis i.e. weight of weevil damaged tubers vs. total tuber yield. The results were subjected to analysis of variance and the treatment means were compared with least significant difference (LSD) test at $\alpha=0.05$.

\section{RESULTS AND DISCUSSION}

\section{Laboratory bioassay}

The statistical analysis indicates that there are no interactions between treatment and stages of the life cycle of the weevil. This suggests that $S$. feltiae and $H$. megidis infest larvae, pupae and adults of the weevil equally well. The effect of two bio-control agents and control treatment on the mortality of larvae, pupae and adults of Cylas formicarius at 24, 48 and $72 \mathrm{hr}$ after inoculation are shown in Fig.1.

Percentage mortality of adult, larvae and pupae were significantly $(\mathrm{p} \leqq 0.05)$ higher in both nematode treatments than in the control treatment. $H$. megidis yielded approximately $80-90 \%$ mortality while mortality in $S$. feltiae treatment was about $70-80 \%$. This reveals that $H$. megidis is more effective in controlling the weeevil than $S$. feltiae in the laboratory condition. Mortality of all three stages, larval, pupal and adult increased with time. In control treatment, less than $25 \%$ of larval, pupal, and adult mortality was observed at 48 and $72 \mathrm{hr}$.

2. Mini plots

Figs 2 and 3 illustrate effect of different treatments on mean percentage damage of stems and tubers of two sweet potato varieties, CARI-426 and CARI-426-13 due to sweet potato weevil at three and a half months after infestation. Analysis of the results indicated a significant variety $\times$ treatment interactions $(\mathrm{p}$ $\leqq 0.05$ ). The percentage damage of stems (\% weight of damaged stems) in the variety CARI-426 was less than that of variety CARI-426-13. This is due to higher sugar content $(9.0 \%)$ of tubers of variety CARI-426 than in CARI-426-13 (5.5\%) (5). However, the damage done by the weevil to both stems and tubers can affect the crop yield (3). Further, significant difference in mean $\%$ damage of tubers and stems $(8 \mathrm{~cm}$ from the base of the sweet potato vine) was observed among all the treatments, two biocontrol agents, carbofuran and infested (control) in mini plot study. Percentage damage of tubers and stems of both sweet potato varieties applied with $H$. megidis and S. feltiae were significantly lower ( $\leqq$ $15 \%$ ) than that in other two treatments. However, the level of weevil damage in tubers of the potato variety CARI-426 was significantly higher in $H$. megidis plots than in plots treated with $S$. feltiae. Levels of pest damage to stems of both varieties and tubers of the variety CARI-426-13 did not differ between nematode treatments. This may be due to favorable weather conditions during in the mini plot study, which facilitated the survival and multiplication of nematodes in the soil. Substantial rainfall coupled with weekly irrigation before and after nematode inoculation provided adequate soil moisture (30\%) 


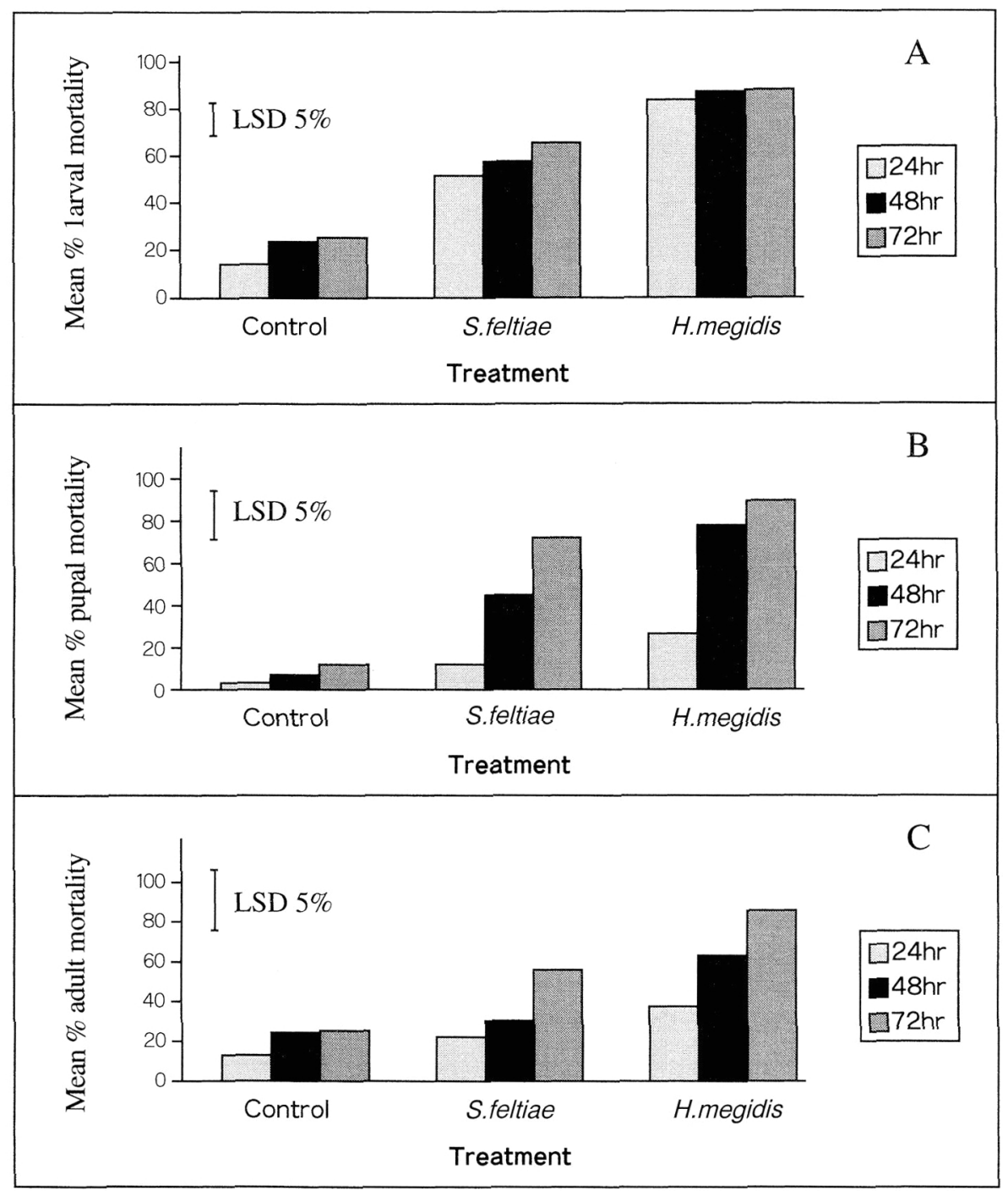

Fig. 1. Effect of entomopathogenic nematodes on different stages of Cylas formicarius at 24, 48, and $72 \mathrm{hr}$ after inoculation. A: Larval mortality. B: Pupal mortality. C: Adult mortality.
I LSD 5\%
$\square$ Variety CARI- 426
Variety CARI-426-13

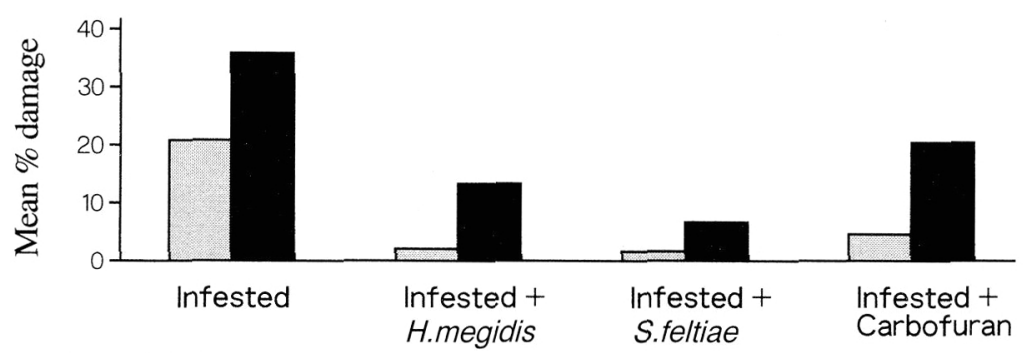

Fig. 2. Effect of different treatments on mean \% damage of stems of sweet potato varieties CARI-426 and CARI-426-13 attacked by Cylas formicarius. 


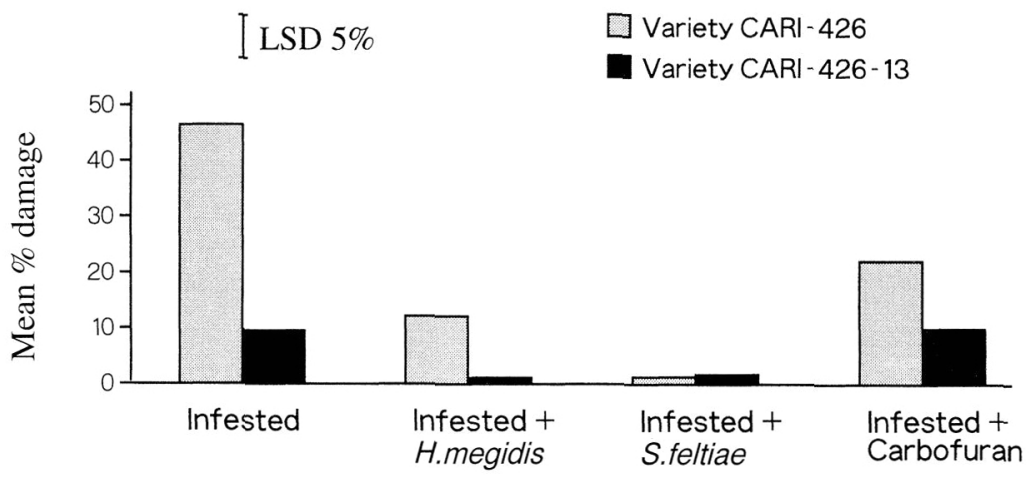

Treatment

Fig. 3. Effect of different treatments on mean \% damage of tubers of sweet potato varieties CARI -426 and CARI-426-13 attacked by Cylas formicarius.

during the investigation. Also mean soil temprature was $25^{\circ} \mathrm{C}$ in which infective nematodes are most active (7). The soil in mini plot was fertile. Vines of both varieties grew rapidly and covered the ground within a short period of 6 weeks time. This condition was also helpful for protecting soil moisture and keeping soil temperature at desired levels for nematode multiplication. Significant differences in percent damage of stems and tubers were observed between carbofuran and control treatments. However, mean damage of tubers and stems in the carbofuran treatment was considerably higher than that of the biochemical treated plants. The cryptic nature of the larvae and pupae of the weevil is likely the main reason for low effectiveness of the carbofuran in controlling the weevil.

\section{3 . Field efficacy test}

Table 1 indicates the mean damage of tubers of the variety Wariyapola Red in different treatments under field conditions. Untreated control resulted in high tuber damage, of about $52.5 \%$ while $H$. megidis resulted in lower tuber damage, about 7\%. S. feltiae and carbofuran treatments gave significant reduction in weevil damage over the untreated control. However, contrary to the observation made in mini plot study, performance of $S$. feltiae was inferior to $H$. megidis under field condition. These nematodes are sensitive to soil moisture levels, sunlight and soil temperature $(4,7)$. At the time of nematode inoculation, the average soil temperature was unfavorable for multiplication. During the cropping period the soil temperature fluctuated between $30^{\circ} \mathrm{C}$ and $34^{\circ} \mathrm{C}$ (Fig. 4). This may also have reduced the multiplication of nematodes. Although adequate moisture content was present due to substantial rainfall at the time of inoculation and during first three weeks of the crop, subsequent dry period prevailed until harvest may have seriously affected multiplication of these nematode species. Thus alternate heavy rains, dry spells and high soil temperature present in the field, may have affected nematodes survival, particularly $S$. feltiae, which can not tolerate rapid drying (2). This might be the reason for poor control of the weevil with $S$. feltiae compared to $H$. mergidis in the field condition. Considering the chemicals, carbofuran was relatively poor at controlling the weevil. A rate of $2 \mathrm{~kg}$ a.i./ha at planting as a furrow treatment might not be sufficient to 


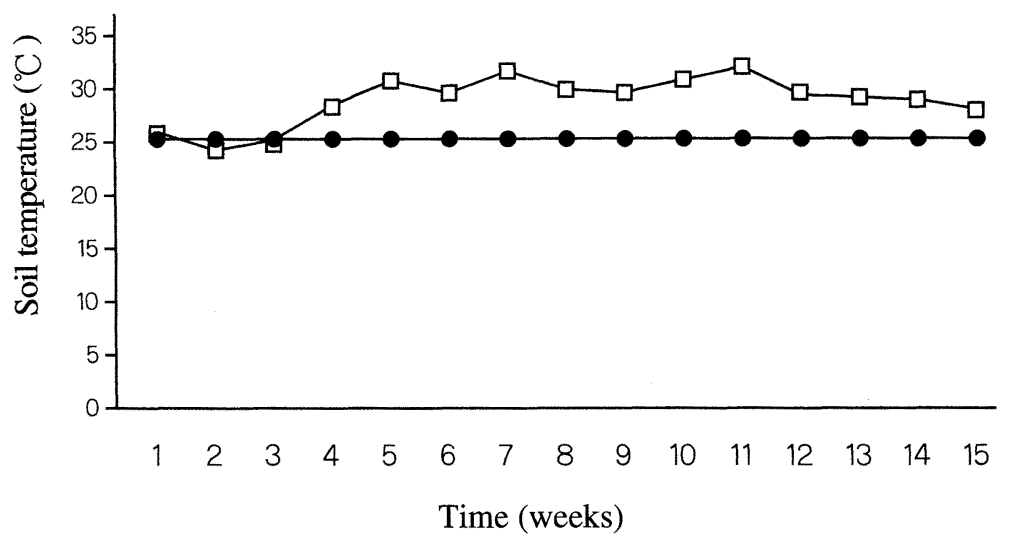

Fig. 4. Fluctuations in soil temperature during the experiment.

$\square$ : Temperature : Optimum temperature

control the higher weevil populations in the field. Control with the insecticide is limited due to the cryptic nature of the larvae and pupae of the weevil that live inside the stems and tubers of sweet potato.

Results of these investigations suggest that Heterorhabditis megidis and Steinernema feltiae can be effectively used to control sweet potato weevil, Cylas formicarius, in sweet potato cultivation. Therefore, these nematodes can be utilized effectively in integrated pest management programmes as an alternative to chemical. Prior to utilizing any foreign bio-control agent for controlling sweet potato weevil, it is essential to investigate the occurrence and identification of locally available entomophathogenic nematodes and evaluate their efficacy in weevil management. Because of the sensitivity of these bio-control agents to temperature fluctuations, it is also important to evaluate their efficacy in different agro-ecological regions in the country.

\section{LITERATURE CITED}

1 ) Bedding, R. A., Molyneux, A.S. \& Akhurst, R. J. (1983) Heterorhabditis spp., Steinernema kraussii: Interspecific and intraspecific differences in the infectivity of insects. Expt. Parasitol. 55, 249-258.

2 ) DutKey, S. R. (1959) Insect Microbiology. Adv. Appl. Microbiol. 1, 175-200.

3 ) EkanayaKe, H. M. R. K., Jayawickrama, H. D. \& de Silva, K. P. U. (1994) Cultural control of sweet potato weevil (C. formicarius). Selected Res. Papers (E. T. RASCO Jr \& V. de R. AMANTE, eds.) 2, 11-14.

4 ) Gaugler, R. R. (1981) Biological control potential of neoaplectanid nematodes. J. Nematol. 13, 241-249.

5 ) Hortical Crop Research and Development Institute, Sri Lanka (1996) Annual report of the root and tuber crop division, $52 \mathrm{pp}$.

6 ) Jansson, R. K., Lecrone, S. H., Gaugler, R. R. \& Smart, G. C. Jr. (1990) Potential of entomopathogenic nematodes as biological control agents of sweet potato weevil (Coleoptera: Curculionidae). J. Econ. Entomol. 83, 1818-1826.

7 KAYA, H. K. (1985) Entomogenous nematodes for insect control in IPM system. In: HoY, M. A. \& HERZOG, D. C. (eds.) Biological control in Agricultural IPM systems. Academic Press, New York, 283-302.

8 ) KAYA, H. K. (1990) Soil ecology. In: GaUGLER. R. R. \& KAYA, H. K. (eds.). Entomopathogenic nematodes in biological control, CRC Press, Boca, Raton, Florida, 93-115.

9 ) Sutherland, J. A. (1986) Evaluation of foliar sprays, soil treatment and vine dip for the control of sweet potato weevil, Cylas formicarius (Fab.). J. Plant protection in the Tropics 3 (2), 95-104. 


\title{
和文摘要
}

\section{スリランカに打ける昆虫病原性線虫のアリモドキゾウムシ (Cylas formicarius) に対する防除効果}

\author{
H. M. R. K. EKANAYAKE・A. M. C. P. AbEYSINGHE ・樋田＼cjkstart幸夫
}

スリランカでサッマイモの重要害虫、アリモドキゾウムシ (Cylas formicarius) の昆虫病原性線虫に 依る防除効果を調べた。サツマイモの芋で飼育したアリモドキゾウムシ（以下、ゾウムシという）の 幼虫、蛹および成虫に市販の昆虫病原性線虫、Heterorhabditis megidis およびSteinernema feltiae の幼 虫をそれぞれ接種した。接種試験は室内のプラスチックシャーレ内、小規模ほ場 $(0.5 \times 2 \mathrm{~m})$ および ほ場で実施した。線虫接種後、ゾウムシ各ステージの死虫率と芋の被害を調べ、無接種区およびカル ボフラン施用区のそれと比較した。シャーレ内では H. megidis 接種ゾウムシは幼虫、蛹、成虫とも 80 -90\%の、またS. feltiae 接種のゾウムシは70-80\%の死虫率をそれぞれ示した。小規模ほ場およびほ場 での試験でもスリランカ育成サツマイモ 2 品種、CARI-426と CARI-426-13栽植の線虫接種区ではゾウ ムシ個体数と芋の被害が無接種区、薬剤両区に比べ、明らかに少なかった。 